Abstracta Iranica Abstracta Iranica

Revue bibliographique pour le domaine irano-aryen

Volume 30 | 2010

Comptes rendus des publications de 2007

« Disposal of the Dead in Planquadrat U/V XVIII at Uruk: A Parthian Enigma? ». Baghdader Mitteilungen, 37, 2006, pp. 267-278.

Vito Messina

(2) OpenEdition

Journals

Édition électronique

URL : http://journals.openedition.org/abstractairanica/37749

DOI : 10.4000/abstractairanica.37749

ISSN : 1961-960X

Éditeur :

CNRS (UMR 7528 Mondes iraniens et indiens), Éditions de l'IFRI

Édition imprimée

Date de publication : 8 avril 2010

ISSN : 0240-8910

Référence électronique

Vito Messina, « « Disposal of the Dead in Planquadrat U/V XVIII at Uruk: A Parthian Enigma? ». Baghdader Mitteilungen, 37, 2006, pp. 267-278. », Abstracta Iranica [En ligne], Volume 30 | 2010 , document 118, mis en ligne le 08 avril 2010, consulté le 26 septembre 2020. URL : http:// journals.openedition.org/abstractairanica/37749; DOI : https://doi.org/10.4000/abstractairanica 37749

Ce document a été généré automatiquement le 26 septembre 2020.

Tous droits réservés 


\title{
« Disposal of the Dead in Planquadrat U/V XVIII at Uruk: A Parthian Enigma? ». Baghdader Mitteilungen, 37, 2006, pp. 267-278.
}

\author{
Vito Messina
}

In this paper, the Author discuss a change from flexed to extended burial, observed at Uruk in locus U/V XVIII around the time of the Parthian annexation of Babylonia. He particularly focuses on the question whether this annexation could explain the introduction of the extended burial practice in the light of a number of related issues, namely the Parthian influence or the influence of Zoroastrian burial practices. Given the Zoroastrian proscription against corpses coming into contact with the Earth, he rightly points out that the Zoroastrianism of the Parthians must make one pause before attributing in-ground burials to it and he proposes other theoretical possibilities giving reasonable explanations for this change. Indeed, with the continuous Parthian control over Babylonia the possibility that ethnically diverse troops came to be stationed in this region increases greatly and in the $2^{\text {nd }}-1^{\text {st }}$ century $B C$ different causes brought into Babylonia foreign groups other than Parthians as permanent or semi-permanent residents.

\section{INDEX}

Thèmes : 3.2.3. Séleucides, Parthes et Sassanides 


\section{AUTEURS}

VITO MESSINA

Università di Torino 